\title{
Right to State Appointed Counsel in Criminal Case: The Constitutional Requirements and the Issue of Its Implementation in Sidama Zone and Hawassa City Courts
}

\author{
Filata Gigiso Boroje \\ School of Law, Hawassa University, Hawassa, Ethiopia \\ Email: filatagigiso@gmail.com
}

How to cite this paper: Boroje, F. G. (2018). Right to State Appointed Counsel in Criminal Case: The Constitutional Requirements and the Issue of Its Implementation in Sidama Zone and Hawassa City Courts. Beijing Law Review, 9, 39-52. https://doi.org/10.4236/blr.2018.91003

Received: December 22, 2017

Accepted: March 6, 2018

Published: March 9, 2018

Copyright $\odot 2018$ by author and Scientific Research Publishing Inc. This work is licensed under the Creative Commons Attribution International License (CC BY 4.0).

http://creativecommons.org/licenses/by/4.0/ (c) (i) Open Access

\begin{abstract}
To preserve cherished principles of democracy in adversary criminal procedures, many democratic states provide for right to hired or state appointed counsel to strike balance between law ignorant defendant and law expert prosecutor. The FDRE constitution also provides for right of indigents to state appointed counsel without further details about its implementation, which resulted in varied practices in determining indigence, nature of eligible cases and time of representation. This study, therefore, was conducted with the view of investigating status of its implementation, the constitutional requirements and how such requirements, including the time of representation are treated by courts. To this effect, the research has adopted mixed approach with interview and analysis of dead files as major data collection tools from selected courts. Combined results show courts apply flexible criteria to determine indigence, but with limited cases of and no pretrial state appointed representation, thereby high likelihood for miscarriage of justice.
\end{abstract}

\section{Keywords}

Right to Counsel, Appointed Counsel, Indigence, Hired Counsel

\section{Introduction}

\subsection{Meaning and Historical Development of Right to Defense Counsel}

Man seeks justice. He has a quenchless thirst to live in just world with peace and security (Kamisar et al., 2002). However, this thirst of man cannot be easily 
achieved due to different reasons, inter alia, injustice and insecurity, caused by criminals, greedy fellow individuals and some unfair provisions of laws themselves. There are criminals here and there who offend social order and disturb man's just, peaceful, ordered and secured life (Ibid). Accordingly, man has established different institutions to deal with these kinds of sections of the society.

State is one of such institutions; to deal with securing justice, peace and order, it uses its Justice Administration Institutions to achieve the objectives it is entrusted with. Among others, court, public prosecutions office, and police are some of the Justice Administration Institutions of the state established with principal task of administering justice in every country of the modern world. Among other mechanisms, procedures are the main means by which justice of a given country is administered (Parmelee, 1911). Accordingly, different countries of the world with modern legal systems have formulated or adopted comprehensive and detailed rules of court procedures (George, 1990). Broadly speaking, justice may be classified as criminal justice and civil justice (Coleman, 2000).

Criminal procedure is employed to administer criminal justice. The functions of criminal procedure are two-one positive, the other negative (Parmelee, 1911). Its positive function is to apprehend every criminal; its negative function is to prevent as far as possible the prosecution and certainly the condemnation of any innocent person (Ibid). The ideal procedure, therefore, would be too firm to permit the escape of a single criminal and yet sufficiently flexible to prevent the prosecution, and especially the condemnation, of any innocent person (Ibid). The two fundamental types of criminal procedure are the procedure of accusation (adversary) and the procedure of investigation, or inquisitorial procedure (Ibid, Bekker, 2004).

Inquisitorial system is a procedural system where courts can actively participate in the litigation process (Ibid). With guiding hand of the court, litigants can proceed without any difficulty (Dolores, 2002). Adversary system, on the other hand is a system where parties shoulder much of the tasks during litigation (Bekker, 2004). Parties should present their case, make oral argument to persuade the court and confront with the evidences of the opponent (Dolores, 2002). These tasks require knowledge of law and how it functions in a given system. As few accused persons only have legal knowledge that enable them to carry out these tasks, vast majority of law-ignorant accused face legally-trained prosecution (Dolores, 2002). This obviously creates imbalance and results in unfair justice by resulting in different evils in adversary system, inter alia, affecting the accused's rights to equality, right to be heard and right to adequately defend oneself (Ibid). Accordingly, through time, the process of "leveling the ground" had been recognized by recognizing one's right to representation by legal experts (US Supreme Court, 1932; Wanda, 1996; Pye, 1982). This is what is called a "right to defense counsel".

The right often includes the right of indigent accused for court appointed 
counsel (Kamisar et al., 2002). A justification for right to counsel, therefore, emanates from the need to mitigate palpable injustice resulting from adversary procedure (Parmelee, 1911). In adversary system, the right to be heard (due process right) would be in many cases of a little avail if it did not comprehend the right to be heard by counsel (US Supreme Court, 1932). Therefore, the right to counsel in criminal proceedings is one of a fundamental right of the Accused person (US Supreme Court, 1942).

Initially, this right was exercised only by persons who can hire their own lawyers. Later, however, this right was extended to indigents by imposing duties on states to provide lawyers for those who cannot hire one (The Allen Report, 1963; Banda, 1996). This imposition of duty is justified on different grounds, inter alia, the principle of equality, a duty on the actor to avoid reasonably avoidable injuries when its conduct, however legitimate, entails a possibility of serious injury to person (The Allen Report, 1963). It was noted that any person haled into court, who is too poor to hire a lawyer, cannot be assured a fair trial unless counsel is provided for him (US Supreme Court, 1963). Therefore, many states in these days extended the "Right to Counsel" to indigents, as well, by providing appointed lawyers for those who, for financial disability, couldn't hire their own lawyers (Green, 2013; Banda, 1996).

When it comes to historical development of the right to counsel, a look at early English law reveals that the right to counsel had "surprisingly modest beginning" (Kamisar et al., 2002). In England, originally only those accused of minor offenses could be represented by counsel (Kamisar et al., 2002; Parmelee, 1911). However, against a background of a decade of false treason charges against the Whigs, the Treason Act of 1695 provided that those prosecuted for high treason should be allowed to defend themselves by counsel learned in the law (Kamisar et al., 2002). Later, however, England courts begun to notice the imbalance created when law ignorant defendant had to face expert prosecutor and extended the right to counsel to all types of cases, irrespective of their seriousness (Parmelee, 1911). However, England recognized a right to retain a counsel to argue matters of facts only (Parmelee, 1911).

In American colonies, unlike the practice of England, the general practice was self-representation, later followed by practice of many states granted right to a lawyer (Kamisar et al., 2002). It is a Sixth Amendment to the US Constitution that has formally granted a right to legal representation by counsel of one's own choosing thereby rejecting the restricted British Approach, but no right to have a counsel provided by the government (Ibid). In Powell v. Alabama (1932), the US Supreme Court held that the right to have a state appointed counsel is a logical corollary of the constitutional right to be heard by counsel, thereby making right to appointed counsel the constitutional right of indigents.

Some of African experiences also show that right to counsel is very recent and post colonial developments (Banda, 1996). In Ethiopian, the right to counsel is formally recognized by the FDRE Constitution (FDRE, 1995). In Article 20(5), 
the Constitution entitles accused persons to be represented by legal counsel of their choice. The Constitution further recognizes the reality of indigence in the society and states, "[i]f they (the accused persons) do not have sufficient means to pay for it (legal counsel of their choice) and miscarriage of justice would result, to be provided with legal representation at state expense" (Ibid, emphasis added).

The constitution has conditioned enforcement of this right to meeting of two requirements; one, the right is exercisable only by indigents-accused persons with no sufficient means to hire their own counsel-and, two, the potential for miscarriage of justice if no representation is made by counsel. If these two requirements are met, the Ethiopian governments, be it Federal or State, have a constitutional duty to level a ground by providing the accused person with legal counsel at the state expense (Dolores, 2002). This duty is evident from the constitution's Article 13 (1) that provides; "All Federal and State legislative, executive and judicial organs at all levels shall have the responsibility and duty to respect and enforce the provisions of [this Chapter]"- the chapter in which right to state appointed counsel is one (FDRE, 1995).

Besides providing for the right to state appointed counsel, the Constitution, however, does not provide for details as to how this right is to be practically implemented. Neither subordinate law for its implementation has been enacted so far. This has created difficulties in determining who is entitled for the right, what types of cases are qualified for appointment of counsel and what is an appropriate time for state appointed representation. Therefore, the level of practical implementation of the right, and the way courts are dealing with it in terms of cases to be represented and the time of representation needs to be investigated. These are points where this research has stepped in with the objective of investigating how indigence is being determined, what type of cases are being provided with state appointed counsel, and at what stage of the proceeding; and assessing the level of practical implementation of this right.

\subsection{The Concept of Poverty and Determination of Indigence}

The concept of poverty and poor is an elusive one and the difficulties of definition are substantial, resulting in different criteria to define it (The Allen Report, 1963). Definitions of poverty and its causes vary by gender, age, culture, and other social and economic contexts (World Bank, 2016). Poverty creates different problems in different aspects of human life. Thus in criminal process a problem of poverty may arise at each stage of proceedings (The Allen Report, 1963). Among others, there is a problem if defendant is unable to obtain pretrial release by reason of financial inabilities to meet the bail requirements, or to retain a lawyer to represent him at the trial, thereby necessitating state intervention with appointed counsel (Ibid). However, the question "who is an indigent to be qualified for state appointed counsel?" is not precisely determined and has frequently attracted court attentions that have resulted in many tests to deter- 
mine indigence. Some of the tests are discussed as follows.

1) “Absolute Inability" Test

According to this test, the defendant is required to show total absence of all means and resources to hire his own lawyer (Kamisar et al., 2002). At the early stage, this test was used to determine indigence. The test, obviously excludes many, who, though not absolute poor, have no sufficient means to pay for counsel ( $I$ bid $)$. As a result, it was abandoned in favor of relative inability test.

2) "Relative Inability" Test

According to this test, the constitutional right to appointed counsel is not conditioned on showing of total destitution. Rather, the criterion appears to be a lack of financial resources adequate to permit the accused to hire his own lawyer (The Allen Report, 1963). Therefore, poverty (indigence) must be viewed as a relative concept with the consequence that the poverty of accused must be measured in each case by reference to the particular need or service under consideration (Ibid).

3) "Cumulative Consideration" Test

According to this view, the concern with poverty and administration of criminal justice requires attention to be extended beyond those who are unable at the outset of the proceedings to hire a counsel (Kamisar et al., 2002). It requires consideration, also, of those who, although possessing means to obtain some elements of an adequate defense (such as hiring a lawyer), lack means to secure other essential elements (such as release on bail, pretrial investigation, testimony and others). Therefore, courts should consider an indigent's responsibility to fund all these elements and, determine indigence accordingly (The Allen Report, 1963).

\section{4) “Temporary Inability” Test}

According to this test, defendants who face current and temporary shortage of the means to hire their own lawyer should be provided with state appointed counsel (Kamisar et al., 2002). Similar rule applies to those defendants who have property, but lack liquidated amount to pay for a lawyer, yet in imminent need of it. In this test, it is generally accepted that the defendant who was provided with state appointed lawyer for his temporary inability should reimburse the state when his temporary incapability ceases to exist (US Supreme Court, 1974).

Besides these major tests, courts also considered the question "whether a private attorney would be interested in representing the defendant in his present economic circumstances?" as a test of eligibility for appointed counsel (Kamisar et al., 2002). A.B.A Standards also provides that the right to court appointed counsel should not be denied merely because friends or relatives have resources adequate to retain counsel (Ibid).

While these are the tests developed by different institutions and individuals, there is not a clear law, court decision or other guidelines that help Ethiopian courts in determining indigence as required by the constitution. 


\subsection{Types of Cases Presence of Appointed Counsel Is Required}

Initially, as it has been noted earlier, right to assistance of counsel was recognized only in minor crimes. Later on, however, due to different reasons, the right was extended to more serious crimes. This was a practice largely followed by American Courts. In these courts, initially counsel was not allowed in minor crimes (US Supreme Court, 1942). Later on however, the US Supreme court noted importance of counsel, not in terms of the crime, but in terms of the question involved in a given case (US Supreme Court, 1972a). Accordingly, they developed the "Complexity of the Case" theory (Kamisar et al., 2002).

Abandoning this theory, again, the court later developed the "Special Circumstances" rule, according to which, counsel is to be provided irrespective of the nature of case or complexity of question it involves if special circumstances-including the accused's identity and the capacity to defend themselveswarrantees the counsel's assistance (Ibid, Green, 2013).

Under all these rules, however, counsel is provided only for serious cases and minor and petty offences for instance, were not considered for appointment of counsel. Later on, citing Chandler v. Fretag (1954) where the absolute right to retained counsel had been recognized, Justice Douglas struck down a rule requiring that counsel be appointed only for non-petty offenses punishable by more than six months imprisonment. He held that "absent a knowing and intelligent waiver, no person may be imprisoned for any offence, whether classified as petty, misdemeanor or felony unless he was represented by counsel" (US Supreme Court, 1972b). The Justce Douglas' and others' emphasis on necessity of a counsel in all types of cases was evident from his opinion that the requirement of counsel may well be necessary for a fair trial even in petty offence proceedings. Improper imprisonment, even for a while, amounts to violation of a person's liberty and dignity, thereby resulting in injustice (Ibid).

The other justification for provision of state appointed counsel in all criminal cases is the one based on the principle of equality. Almost all states granted unqualified right to assistance of counsel one can hire. Those who can hire their own counsel, therefore, enjoy unqualified right and can hire a lawyer even for petty offences and the principle of equality similarly demands unqualified right to appointed counsel (US Supreme Court, 1961). The only exception in this regard is that a state has no duty to provide a lawyer for petty offences that do not result in deprivation of liberty.

This interpretation equally holds for Ethiopia. Deprivation of liberty, even for a while could result in miscarriage of justice; and denying unqualified right to counsel also goes against the principle of equality enshrined in the FDRE constitution. Accordingly, Ethiopian courts have constitutional responsibility to avoid any practices that may result in violation of the equality principle; and hence injustice. Therefore, the state appointed counsel should be provided for all accused indigents irrespective of the nature (seriousness) of the case. 


\subsection{Time of Representation by Appointed Counsel}

Generally speaking, there are three critical times of criminal proceeding, namely, pretrial, trial and appeal stages (The Empire of Ethiopia, 1961). What is the relevant time for representation, then, is relevant question to be addressed. In this regard, the US practice shows that the right to counsel initially was considered as only necessary when an accused is criminally prosecuted (US Supreme Court, 1972a). These days, however, there are two rules. The first is "Criminal Prosecution Rule" (US Supreme Court, 1973) and the other is "The Critical Stage Rule" (US Supreme Court, 1966).

According to the "Criminal Prosecution" Rule, a defendant is not entitled to the assistance of counsel, unless adversary judicial proceedings have commenced against him (US Supreme Court, 1973). Accordingly, a defendant cannot request for appointment of counsel especially at the time of custodian interrogation, pretrial lineups and preliminary hearings. Later on, however, owing to importance of counsel in criminal proceedings, the "Criminal Prosecution Rule" was criticized and replaced by the "Critical Stage Test".

According to the critical stage test, whether the defendant is entitled for a lawyer at a given stage is to be evaluated by evaluating whether that stage is critical (Ibid, dissenting view). A stage of proceeding must be deemed critical if it is one at which the presence of counsel is necessary to protect the fairness of the trial itself. Viewed in this sense, pretrial stage of proceeding is "critical stage" as it is a stage where custodian interrogations are made, evidences for trial are collected, and preliminary hearings are conducted. Moreover, suspect's bail right - that is crucial for the suspect to collect and organize her defense-is also determined at this stage (The Empire of Ethiopia, 1961). All these tasks have the effect of determining the whole proceeding and its fairness, thereby making the counsel's presence a necessity. Failure to appoint a counsel for accused person at this stage, therefore, amounts to the court's failure to protect fairness of the whole proceeding (US Supreme Court, 1973, Dissenting view).

It is also noted that those who hire their own counsel are free to have their counsel at any stage of criminal proceeding, and leaving an indigent accused unrepresented for a mere reason of his economic status also results in discrimination based on property status, which, in turn violates the constitutional principle of equality before the law and equal treatment of law (Bekker, 2004; FDRE, 1995).

Similar interpretation applies to the case of Ethiopia for two reasons. The first is that the FDRE Constitution mandate appointment of counsel where there is a potential for miscarriage of justice, and due to critical nature of pretrial proceedings in the Criminal Procedure Code, there is an obvious potential for miscarriage of justice if indigents are left unrepresented.

The second reason is, the Constitution mandates interpretation of its third chapter-the Chapter dealing with human and democratic rights where the right to counsel is one-to be in conformity with the international instruments Ethi- 
opia has ratified or is a party (FDRE, 1995). The ICCPR, which Ethiopia has ratified, clearly states that a pretrial stage of criminal proceeding is a crucial stage where legal representation is a necessity (Lawyers Committee for Human Right, 2000). Due to these two reasons, therefore, Ethiopian courts are under the constitutional obligation to appoint a counsel for indigents beginning from the time of their arrest.

\section{Materials and Methods}

\subsection{The Research Design}

The researcher has employed mixed research design that mixes both qualitative and quantitative research designs. Two major data collection tools, interview for qualitative data, and analysis of closed files for quantitative data, have been used for collection of primary data. Books, cases, articles, laws and other formal and informal documents have been used as secondary data inputs.

\subsection{Institution Selection}

Hawassa City High Court, Hawassa City first instance court Menaharia Main and Tabour Division; HawellaTulla first instance court main division, Sidama Zone High Court, and three woreda courts-namely Boricha, AletaWondo and Hulla-from Sidama Zone are selected purposively based on their case load and the university's industry village.

\subsection{Sampling Techniques}

Interview respondents (Table 1 ).

\section{Cases}

Taking the year 2012 G.C as a bench mark, decisions between 2011 and 2015 E.C were selected for a case study. Equal numbers of files have been considered from each court except those three Wereda courts whose cases appeared by appeal to Sidama Zone High Court have been studied. All studied cases were rendered by

Table 1. Summary of individuals participated in interview.

\begin{tabular}{ccccc}
\hline No. & Institution/Profession & $\begin{array}{c}\text { No. of } \\
\text { interviewees }\end{array}$ & $\begin{array}{c}\text { Selection } \\
\text { Criteria }\end{array}$ & Justification for selection \\
\hline 1 & $\begin{array}{c}\text { Courts, Judges, } 2 \text { from each } \\
\text { courts except Wereda courts }\end{array}$ & 10 & Purposive & Criminal bench experiences \\
2 & Police Stations, Polices & 4 & Accidental & Availability at a time \\
3 & Hawassa University, Lecturers & 2 & Purposive & Human rights/constitution experts \\
4 & $\quad$ Advocates & 3 & Purposive & Work experience in Hawassa courts \\
5 & $\begin{array}{c}\text { FedralSupreme Court Defense } \\
\text { Lawyer }\end{array}$ & 1 & Purposive & The only oneat the court \\
6 & Detainees in the police stations & 4 & Accidental & Availability at a time \\
\hline
\end{tabular}


relevant court in its first instance jurisdiction. Total of 225 cases have been studied. Cases were purposively identified on basis of their relevance and from identified files, selected cases were selected randomly as they are found in the lists of files in the archive.

\subsection{Sample Size}

The issue of representativeness of sample was emphasized and ample number of cases have been considered. However, representativeness was not scientifically determined, yet conclusions are not hasty. Generally, 29 interviewees and 225 cases have been considered.

\subsection{Data Analysis Technique}

\subsubsection{Qualitative Data}

Qualitative data was categorized under certain theme in the way that helps to address the research questions.

\subsubsection{Quantitative Data}

Quantitative data was analyzed manually by using some statistical methods. Accordingly, data was analyzed, summarized and implications were drawn according to their relevance to the research questions.

Both qualitative and quantitative data is analyzed in terms of some important issues like nature of cases, status, source and time of representation. Results of both quantitative and qualitative study are summarized and provided in the next section.

\section{Implementation of Right to State Appointed Counsel in the Study Area}

Concerning determination of indigence, accused indigents are often ordered to prove their financial status. Certificate from kebele, witnesses, and other documents are admissible in these courts. Courts do not follow stringent criteria in determining indigence. Sometimes, courts even do not require proof of indigence and grant defense lawyer when one is required by the accused person. No request that was made for appointment of counsel has been rejected so far. The only problem in this regard is that courts, instead of informing indigents of their right to appointed counsel, wait until the request is made by the defendant. Partly, this is due to absence of such procedure in the criminal procedure.

Table 2 summarizes nature of cases studied and their representation status.

Table 2 explains overall result of case analysis against the two important issues, namely, nature of cases and representation status. The vast majority (67.6\%) of studied cases went unrepresented. It also shows that $57.8 \%$ of the studied cases were less serious in terms of crimes the defendants were charged with.

The right to counsel in general is not well exercised in these courts. Only $32.4 \%$ of the studied cases have been represented. This right is one of the list ex- 
ercised rights of the constitution. It, in general, is not exercised except in a few serious cases.

The following Table 3 presents overall data in terms of representation and the nature of cases combined.

Table 3 shows that from all cases, only 7.55\% of less serious cases have been represented. Representation within less serious cases is only $13.08 \%$, i.e. this percent of less serious cases only had been represented by counsel. $23.29 \%$ of the represented cases were less serious cases, while the huge amounts of represented cases $(76.71 \%)$ were serious ones.

Counsel is most often sought for more serious cases. Almost all less serious cases go unrepresented. Most of the times, persons accused of less serious cases are young and poor, lacking both awareness and resource to hire their own counsel. On the other hand, courts do not provide appointed counsel for less serious crimes. Unlike less serious cases, persons accused of grand crimes like corruption are often literate and have resources. Due to these reasons, more serious cases are better represented than less serious ones.

Table 4 summarizes the data in terms of another important issue, the source of representation.

According to Table 4, 9.33\% of all studied case were represented by court appointed counsel. It also shows that vast majority (71.24\%) of all represented cases were represented by counsels hired by defendants themselves. From all represented

Table 2. Summary of results in terms of nature of case and representation status.

\begin{tabular}{cccc}
\hline No. & Description & Number of files & Percent \\
\hline 1 & Serious cases & 95 & 42.2 \\
2 & Less serious cases & 130 & 57.8 \\
3 & Represented cases & 73 & 32.4 \\
4 & Unrepresented cases & 152 & 67.6 \\
\hline
\end{tabular}

Table 3. Summary of case study results in terms of combined elements of nature of case and representation.

\begin{tabular}{cccccc}
\hline No. & Description & Number & $\begin{array}{c}\text { Overall } \\
\text { percent }\end{array}$ & $\begin{array}{c}\text { Percent of } \\
\text { the category represented/unrepresented }\end{array}$ & $\begin{array}{c}\text { Percent in } \\
\text { the }\end{array}$ \\
\hline 1 & Serious and represented & 56 & 24.88 & 58.95 & 76.71 \\
2 & Less serious represented & 17 & 7.55 & 13.08 & 23.29 \\
3 & Serious unrepresented & 39 & 17.33 & 41.25 & 25.66 \\
4 & Less serious and unrepresented & 113 & 50.22 & 86.92 & 74.34 \\
\hline
\end{tabular}

Table 4. Summary of cases study in terms of sources of representation.

\begin{tabular}{ccccc}
\hline No. & Source of representation & No. of cases & Percent/overall & Recent/category \\
\hline 1 & Own lawyer & 52 & 23.11 & 71.24 \\
2 & State appointed lawyer & 21 & 9.33 & 28.76 \\
\hline
\end{tabular}


cases, representation by state appointed counsel is $28.76 \%$.

Few cases only are provided with court appointed counsel due to insufficiency of resources to provide all indigents with appointed counsel. There are only few-most often one-defense lawyers in some courts, still many courts even without a single defense lawyer. Moreover, resources, both financial and material, allocated for this purpose is insignificant. Most defense lawyers are less paid, with no independent furnished rooms, with no electronics, stationaries or secretarial services; merely sharing office with either court officers or other court employees. They cannot independently and confidentially talk to their clients. As a result, they can handle only limited number of cases, many cases being proceeded with in absence of lawyers.

The following Table 5 describes summary of results for source of representation combined with nature of case and time of representation.

Table 5 shows that $7.56 \%$ of all studied, and $23.29 \%$ of all represented cases were less serious cases represented by hired lawyers. From own representation $32.69 \%$ were representations for less serious cases. On the other hand, there is no less serious case provided with state appointed counsel at all (100\%) of state appointed representations were for serious cases.

The study discovered that courts appoint counsel for persons accused of serious crimes with minimum of ten years or above imprisonment. No representation is provided for crimes that entail below ten years imprisonment, Even though it is agreed up on importance of counsel for these types of cases. Although there is no written guidelines or laws in this regard, interviewees said, this has been practice of courts from a long time ago. The only exception to this, which was not supported by a single example, is the case of women, juvenile offenders and other vulnerable groups. Except in petty offenses and offenses entailing less than one year imprisonment, some judges stated they would appoint free counsel for these groups even for less serious crimes. Not a single woman has been found to receive court appointed counsel at their trial, neither were they informed of this right. Again this limited provision of appointed counsel was justified on insufficiency of resources. Moreover, failure of indigents to request for appointment is also taken as another reason.

In terms of time of representation, the table shows that $20.54 \%$ of all represented cases and $28.85 \%$ of all own representations were made at pretrial

Table 5. Data summary in terms of source of representation combined with nature of case and time of representation.

\begin{tabular}{cccccc}
\hline No. & Description & $\begin{array}{c}\text { No. of } \\
\text { cases }\end{array}$ & $\begin{array}{c}\text { Overall } \\
\text { percent }\end{array}$ & $\begin{array}{c}\text { Percent/all } \\
\text { representation }\end{array}$ & $\begin{array}{c}\text { Percent/all own } \\
\text { representation }\end{array}$ \\
\hline 1 & Less serious, own representation & 17 & 7.56 & 23.29 & 32.69 \\
2 & Pretrial own representation & 15 & 6.67 & 20.54 & 28.85 \\
3 & Serious, state appointed representation & 21 & 9.33 & 28.76 & 100 \\
& Trial state appointed representation & 21 & 9.33 & 28.76 & 100 \\
\hline
\end{tabular}


Table 6. Summary of eligibility of defendants for state appointed counsel.

\begin{tabular}{cccccc}
\hline No. & Description & $\begin{array}{c}\text { No. } \\
\text { of cases }\end{array}$ & $\begin{array}{c}\text { Percent/ } \\
\text { all cases }\end{array}$ & $\begin{array}{c}\text { Percent/ } \\
\text { all unrepresented }\end{array}$ & $\begin{array}{c}\text { Percent/ } \\
\text { all indigents }\end{array}$ \\
\hline 1 & Potential indigents, not represented & 119 & 52.88 & 78.28 & 85 \\
2 & Indigents, represented & 21 & & & 15 \\
\hline
\end{tabular}

stages. On the other hand, all (100\%) of state appointed counsels were provided at a trial time, showing that no state appointed representation was made at pretrial stage.

Appointment of counsel is made by courts only, and police frequently fail to produce arrested persons before courts, making appointment at pretrial stage difficult. Police neither inform accused indigents of their right to appointed counsel. Moreover, arrested indigents in most times do not require appointment of counsel, as they are rarely aware of this right. Even though critical nature of this stage and importance of a counsel to mitigate potential injustice is admitted by many persons, unfortunately, no counsel for indigents is provided at this stage.

Table 6 explains potential indigents who could have been qualified for state appointed counsel, but were not provided with the same.

According to summary in Table $6,52.88 \%$ of all studied and $78.28 \%$ of all unrepresented cases were indigents who should have been provided with court appointed counsel. Together with represented poor, $62.22 \%$ of all studied cases were potentially indigents, and as the table shows, $85 \%$ of these indigents were not provided with court appointed counsel.

The vast majority of accused indigents are not provided with court appointed counsel. However, the situation is getting better through time. Relatively, more defendants than before are receiving court appointed counsel recently. Still, the represented number remains insignificant.

\section{Conclusion}

Indigence is determined by the studied courts by all possible means and this is a good experience that it does not impose technical difficulty in exercise of constitutional right of state appointed counsel. However, the state interest should also be protected by applying reasonable assessment standard to check improper use of this right by persons having sufficient means. Even though all indigents requested for appointment of counsel have received the one, still the number of indigents receiving state appointed counsels is very minimum. Though there are some attempts, they are insignificant compared to number of unrepresented cases counsel should have been provided.

Generally, it can be said that overall implementation of indigents' right to appointed counsel is far below satisfactory. All less serious cases and majority of serious cases are also left unrepresented; and concerning time of representation, representation is provided only at trial stage, leaving the critical pretrial stage 
unrepresented. Due to time of representation and number of unrepresented cases, the possibility for miscarriage of justice is very likely.

Courts are there to respect and enforce the constitution and rights enshrined therein. However, these courts' frequent failure to appoint counsel for all indigents at a proper time is against their constitutional obligation to respect and enforce the right to state appointed counsel, thereby allowing potential miscarriage of justice as provided for by the constitution. Therefore, the issue of implementing constitutionally guaranteed right to counsel of accused indigents needs immediate action on part of all concerned authorities, more specifically the courts.

One of the big problem in implementing of this right to state appointed counsel is absence of law regulating determination of indigence, nature of cases representation is allowed and the stage of appointment. There is no clear law also that governs establishment, responsibilities and benefits of the defense lawyers. Therefore, the first and most important move in improving implementation of this right is enacting the law governing all these and other issues relating to this right.

\section{Acknowledgements}

I would like to thank Hawassa University, Office of Vice President for Research and Technology Transfer for funding this research. My Heartfelt thanks also go to Mr. Shimeles Ashagrie for all goods he has done.

\section{References}

Bekker, P. M. (2004). The Right to Legal Representation, including Effective Assistance, for an Accused in the Criminal Justice System of South Africa. The Comparative and International Law Journal of Southern Africa, 37.

Coleman, J. (2000). Philosophy of Law (6th Ed.). Wadsworth.

Dolores D. (2002). The Judicial Duty to Protect and Enforce Constitutional Rights of Accused Persons Unrepresented by Counsel. Ethiopian Law Review, 1.

FDRE (1995). The Constitution of the Federal Democratic Republic of Ethiopia. Proclamation No. 1/1995.

George, B. J. (1990). Rights of the Criminally Accused. Law and Contemporary Problems, 53, 71-107. https://doi.org/10.2307/1191843

Green, B. A. (2013). Gideon's Amici: Why Do Prosecutors So Rarely Defend the Rights of the Accused? The Yale Law Journal, 122.

Kamisar, Y., Wayne, L., Jerold, I., \& Nancy, K. (2002). Modern Criminal Procedure (10th Ed.). West Group.

Lawyers Committee for Human Rights (2000). What Is a Fair Trial? A Basic Guide to Legal Standards and Practices, New York.

Parmelee, M. (1911). Public Defenses in Criminal Trials. Journal of the American Institute of Criminal Law and Criminology, 1, 735-747. https://doi.org/10.2307/1133402

Pye, K. (1982). The Rights of Persons Accused of Crime under the Canadian Constitution: A Comparative Perspective. Law and Contemporary Problems, 45.

The Allen Report (1963). Report of the Attorney GeneraP s Committee on Poverty and the 
Administration of Federal Criminal Justice.

The Empire of Ethiopia (1961). The Criminal Procedure Code of the Empire of Ethiopia, Negarit Gazeta. Extraordinary Issue No. 1/1961.

US Supreme Court (1932). Powell v. Alabama, 287 U.S. 45,53 S.Ct. 55, 77L.Ed. 158.

US Supreme Court (1942). Betts v. Brady, 316 U.S. 455, 62 S.Ct. 1252, 86 L.Ed. 1595.

US Supreme Court (1961). Ferguson v. Georgia.

US Supreme Court (1963). Gideon v. Wainwright.

US Supreme Court (1966). Miranda v. Arizona.

US Supreme Court (1972a). Kirby v. Illinois.

US Supreme Court (1972b). Argersinger v. Hamlin.

US Supreme Court (1973). Kirby v. Illinois.

US Supreme Court (1974). Fuller v. Oregon.

Wanda, B. P. (1996). The Rights of Detained and Accused Persons in Post-Banda Malawi. Journal of African Law, 40, 221-233. https://doi.org/10.1017/S0021855300007786 